\title{
The effects of hydro-alcoholic extract of Artemisia dracunculus L. (Tarragon) on hematological parameters in mice
}

\author{
Mehrdad Modaresi $^{1}$, Mahnaz Alasvand Zarasvand ${ }^{2 *}$, Mahboobeh Madani ${ }^{2}$
}

1. Department of Physiology, Isfahan ( Khorasgan ) Branch, Islamic Azad University, Isfahan, Iran

2. Department of Microbiology, Falavarjan Branch, Islamic Azad University, Isfahan, Iran

*Corresponding author:Tel: +98 9132161138 Fax: +98 3136500833

Address: Department of Microbiology, Falavarjan Branch, Islamic Azad University, Isfahan, Iran

E-mail: mahnaz_alasvand@yahoo.com

Received: 2017/03/28 revised: 2017/05/10 accepted: 2017/05/26

\begin{abstract}
Introduction: Artemisia dracunculus L. (Tarragon) is one of the plants that uses as meal and remedy for a long time, and possesses many medicinal properties. In traditional medicine also has mentioned to its beneficial properties. A number of researches through in vitro and in vivo studies showed the pharmacological properties of this plant. This study was done for determining the effect of hydro-alcoholic extract of A. Dracunculus L. on some hematological parameters among mice.

Materials and methods: In this study, 40 male mice were divided into five groups: a control, a placebo, and three treatment groups that were injected with 50,100, and $200 \mathrm{mg} / \mathrm{kg}$ doses of hydro-alcoholic extract of tarragon every other day for 20 days. At the end of injections, the levels of WBC, RBC, lymphocytes, monocytes, and neutrophils were measured. Statistical analysis was done using SPSS software and analysis of variance (ANOVA) test.

Results: The obtained results showed that there was no significant difference in amounts of $\mathrm{WBC}, \mathrm{RBC}$, and monocytes in the treatment groups in comparison with the control group. Lymphocytes showed significant decrease in groups of 100 and $200 \mathrm{mg} / \mathrm{kg}$ doses than the control group. The level of neutrophils showed significant increase in two treatment groups (100 and $200 \mathrm{mg} / \mathrm{kg}$ ) than the control group.

Conclusion: It can be concluded that the hydro-alcoholic extract of tarragon stimulates the production of neutrophils in this study which can be used as an immunostimulating agent.
\end{abstract}

Keywords: Artemisia dracunculus L., Blood parameters, Hydroalcoholic, Mice

\section{Introduction}

Plants and their derivations have shown beneficial therapeutic effects such as; antioxidant, anti-inflammatory, anti-cancer, anti-microbial and immunomodulatoty properties (1). Herbal medicines are used by about $60 \%$ of the world people in many countries (2). Nowadays, people are interested in using herbal medicine because of some reasons such as side effects of chemical drugs; increasing resistance of microorganisms to many drugs especially antibiotics, and high costs of producing chemical drugs (3). Plants are complementary and alternative medicine due to their ability for producing secondary metabolites such as; proteins, flavonoids, alkaloids, steroids, and phenolic compounds which are used to recover health and cure many diseases (4). For instance, flavonoids in many kind of

Copyright (C) 2018 Journal of Basic Research in Medical Science. This is an open access article distributed under the terms of the Creative Commons Attribution 4.0 International License (https://creativecommons.org/licenses/by/4.0/) which permits copy and redistribute the material, in any medium or format, provided the original work is properly cited. 
plants have been shown possess antiallergic, anti-inflammatory, anti-cancer, anti-oxidant, and anti-carcinogenic activities (5). Artemisia dracunculus L. (Tarragon) is the plant that classified as Kingdom: Plantae, Division: Magnoliophyta, Class: Magnoliopsida, Order: Asterales, Family: Asteraceae, Genus: Artemisia L., Species: Artemisia dracunculus $\mathrm{L}$ (6), is a perennial plant with a woody rhizome. Important bioactive compounds are essential oils, cumarins, flavonoids, and phenolic acids. The main compounds of essential oils are estragol (methyl chavicol) that the content varies from 40 to $60 \%$, and methyl eugenol (7). Therapeutic properties of tarragon like anti-pyretic, anti-febrile effects, and facilitate respiration were noted by Abu Mansur, Avicenna, and Ibn Baitar (8). In traditional medicine A.dracunculus is used to improve malfunctioning digestive, anti-insomnia, anti-epileptic, anti-inflammatory, antimicrobial, flush toxins from body, anesthetic for teeth-ache, anti-spasmodic and treatment carminative. In vivo pharmacological effects of tarragon have been shown some properties such as; hepatoprotective activity, antihyperglycemic action, hypolipidaemic action, anti-oxidant activity, anti-hypoxic activity, and neurotropic activity $(7,9,10)$. Blood parameters like red blood cells, white blood cells, neutrophils, monocytes, and lymphocytes are vital cells in blood circulation, so any increase or decrease in concentration of these cells affect the immunity and the health constitution of the body. Considering the therapeutic properties of tarragon and the basic roles of the mentioned blood parameters, the effect of hydroalcoholic extract of $\mathrm{A}$. dracunculus L. was investigated on hematological parameters in mice.

\section{Materials and methods}

Animals: In this study, 40 male mice (30 $\pm 5 \mathrm{~g}$ ) were provided from Pasteur Institute of Iran and kept in special cages. The mice were housed in a standard condition under $12: 12 \mathrm{~h}$ light / dark period at $24 \pm 5^{\circ} \mathrm{C}$ with free access to water and food. In order to adapting to the new environment, they were kept for a month and then the injections were performed. Approval for this study was given by the Ethical Committee of Islamic Azad University, Falavarjan Branch.

Preparation of extract: After identifying tarragon in Isfahan Center for Research of Agricultural and Natural Resources the leaves were separated, dried in the shade and powdered by electrical grinder. An amount $50 \mathrm{~g}$ of the powder was moved to a sterile Erlenmeyer and ethylalcohol was added until the mixture was suspended. Then the mixture was shaken by a shaker for 48 hours. Afterwards the mix was filtered by filter paper. The obtained liquid was heated in an oven at $40^{\circ} \mathrm{C}$ until the alcohol evaporated. The residual was pure extract. At the end, by adding a definite amount of normal saline, three doses of extract; 50, 100, and $200 \mathrm{mg} / \mathrm{kg}$ were prepared and refrigerated at $4{ }^{\circ} \mathrm{C}$ for injections.

Experimental conduct: The mice were divided into five groups of eight members in each group. The first group was considered as control, the second group as a placebo (which received $0.5 \mathrm{ml}$ normal saline every other day), the third, the fourth, and the fifth groups were received 50,100 , and $200 \mathrm{mg} / \mathrm{kg}$ doses of hydroalcoholic extract via intraperitoneal (i.p) injection every other day for 20 days.

Blood analysis: After the final injections, the mice were anaesthetized and killed by cervical decapitation. Blood samples were collected from cervical artery using heparinized tubes and then centrifuged and analyzed by Cell Counter (PCE 210 ERMA) to determining amounts of RBC, WBC, lymphocytes, neutrophils and monocytes.

\section{Statistical analysis}

Statistical analysis was performed by SPSS software. One-way analysis of 
variance (ANOVA) followed by the Tukey post hoc test was used to compare mean values of quantitative variables among groups. The criterion for statistical significance was $\mathrm{P}<0.05$.

\section{Results}

Table 1 shows the levels of RBCs, WBCs, monocytes, lymphocytes, and neutrophils in three treatment groups in comparison with the control group. The levels of RBC and $\mathrm{WBC}$ in the treatment groups have no significant changes comparing with that of the control group $(\mathrm{P}<0.05)$. Amounts of monocytes slightly increased in two treatment groups (100 and $200 \mathrm{mg} / \mathrm{kg}$ doses). The levels of lymphocytes in two treatment groups (100 and $200 \mathrm{mg} / \mathrm{kg}$ doses) showed significant decrease comparing with the control group $(\mathrm{P}<$ 0.05). The levels of neutrophils in two treatment groups; 100 and $200 \mathrm{mg} / \mathrm{kg}$ doses showed significant increase than the control group $(\mathrm{P}<0.05)$.

Table 1.The results of effect of hydroalcoholic extract of tarragon on blood cells in five experimental groups $(\mathrm{n}=8)$.

\begin{tabular}{|c|c|c|c|c|c|}
\hline & \multicolumn{3}{|c|}{ Treatment groups } & \multirow[b]{2}{*}{ Placebo } & \multirow[b]{2}{*}{ Control } \\
\hline & Dose $50 \mathrm{mg} / \mathrm{kg}$ & Dose $100 \mathrm{mg} / \mathrm{kg}$ & Dose $200 \mathrm{mg} / \mathrm{kg}$ & & \\
\hline \multirow[t]{2}{*}{ WBC } & $2487.50 \pm 331.39$ & $2350.00 \pm 160.37$ & $2387.50 \pm 155.26$ & $2437.50 \pm 118.77$ & $2275.00 \pm 116.49$ \\
\hline & 117.17 & 56.69 & 54.89 & 41.99 & 41.18 \\
\hline \multirow[t]{2}{*}{$\mathrm{RBC}$} & $5.59 \pm .33$ & $5.71 \pm .34$ & $5.9875 \pm .38$ & $5.5625 \pm .05$ & $5.8750 \pm .31$ \\
\hline & 0.12 & 0.34 & 0.13 & 0.02 & 0.12 \\
\hline \multirow[t]{2}{*}{ Monocyte } & $1.87 \pm .99$ & $3.50 \pm 1.60$ & $2.75 \pm 1.03$ & $1.87 \pm .83$ & $2.50 \pm .53$ \\
\hline & .35 & 1.60 & 0.37 & .29 & 0.19 \\
\hline \multirow[t]{2}{*}{ Lymphocyte } & $62.12 \pm 2.47$ & $51.25 \pm 3.28 *$ & $49.25 \pm 3.65^{*}$ & $61.62 \pm 1.85$ & $59.50 \pm .53$ \\
\hline & 0.87 & 1.16 & 1.29 & 0.65 & 0.19 \\
\hline \multirow[t]{2}{*}{ Neutrophil } & $36.00 \pm 2.67$ & $45.25 \pm 2.38 *$ & $48.00 \pm 3.74 *$ & $36.50 \pm 1.20$ & $38.00 \pm .76$ \\
\hline & 0.94 & 0.840 & 1.32 & 0.42 & 0.27 \\
\hline
\end{tabular}

* Statistically significant difference compared with control group $(\mathrm{P}<0.05)$. Data are shown as mean \pm SD and standard error.

\section{Discussion}

Plants and plant extracts have potential to influencing health and cure some diseases. As was described, A. dracuculus L. has remarkable pharmaceutical properties. In this study hydroalcoholic extract of tarragon showed different results on blood parameters because of having various secondary metabolites. In our study the levels of RBC and WBC had no significant changes in the treatments groups. The extract of Crocus sativus and safranal on guinea pigs had shown WBCs in blood was increased. Which was attributed to safranal (11). Ladokun et al, had shown administration of extract of Vicum album (mistletoe) decreased RBC, and increased WBC in rats. Reduction of RBCs had been assumed to be associated with perturbed haemopoeisis and destruction of RBCs, and increase in WBCs was due to containing agent that stimulated the proliferation of leucocytes (2). Blood monocytes develop in the bone marrow and also they may remain in the circulation for long periods. After entering into tissue, monocytes differentiate into tissue macrophages. Macrophages and their circulating precursors, called monocytes, play a basic role in innate and adaptive immunity. They also are important effecter cells for the elimination of foreign substances (12). In the results of this study was showed that the amounts of monocytes slightly increased in two treatment groups (100 and $200 \mathrm{mg} / \mathrm{kg}$ doses), however, it was not statistically significant. Increasing doses of the extract in this research may cause significant changes in the amount of monocytes. Effect of hydroalcoholic extract of 
Ziziphus jujube in Balb/c mice had shown the percentages of monocyte and lymphocytes decreased, and it had been attributed to being triterpenoides in jujube fruit (13). The levels of lymphocytes in the two treatment groups showed significant decrease. Immunomodulatory activity of flavonol glycosides from Euphorbia microsciadia Bioss had shown that antiproliferative activity of lymphocytes was due to inhibiting of protein kinase $\mathrm{C}$ (PKC) enzyme. This enzyme plays an important role in the T-cell activation (14). Amirghofran et al, had shown the extract of various medicinal plants caused lymphocyte inhibitory effects at high doses and it seems to inducing of apoptosis (15). The levels of neutrophils in two treatment groups showed significant increase. Immunomodulatory effect of aqueous extract of Erigeron floribundus (Kunth) leaves stimulated increase of neutrophils and lymphocytes in rabbit blood (16). Immunological effects of Teucrium polium on neutrophil had shown an increase in the neutrophils activity and improvement in their functions (17). Phagocytic cells such as neutrophils and macrophages are important groups which belong to innate immunity system. Innate immunity provides the early line in defending against microorganisms and foreign substances. Production of neutrophils are stimulated by G-CSF (granulocyte colony-stimulating factor) (18). Our results suggest that $A$. dracunculus L. might be effective on neutrophils proliferation as a result of

\section{References}

1. Sharififar F, Pournourmohammadi Sh, Arabnejad M, Rastegarianzadeh R, Ranjbaran O, Purhemmaty A. Immunomodulatory activity of aqueous extract of Heracleum persicum Desf. in mice. Iran J Pharm Res. 2009; 8(4):287-92.

2. Ladokun O, Ojezele M, Arojojoye O. Comparative study on the effects of aqueous extracts of viscum album (mistletoe) from three host plants on affecting G-CSF and consequently boosts the cell-mediate innate immunity.

\section{Conclusion}

In conclusion, a. dracunculus L. (Tarragon) may be recommended for use as immunostimulant in normal and immunocompromized system for protection against various bacteria, viruses, and many diseases due to an increase in the neutrophil cells and boost innate immunity. However, isolation and purification of tarragon components are also needed to find out the effective component(s) and related mechanism(s) of this approach. In addition, investigation of other extracts of tarragon (aquatic, acetonic, etc.) on blood parameters and other infections and diseases are strongly recommended.

\section{Acknowledgments}

This article is based on a post-graduation thesis for the Degree of MSc in microbiology at Falavarjan Branch, Islamic Azad University and was done in Research Laboratory of Islamic Azad University, Falavarjan Branch. The authors are grateful for their adequate facilities and supports.

\section{Conflicts of interest}

None of the authors have any conflicts of interest.

hematological parameters in albino rats. Afr J Health Sci. 2015; 15(2):60612.

3. Sharififar F, Pournourmohammadi S, Arabnejad M. Immunomodulatory activity of aqueous extract of Achillea wilhelmsii C. Koch in mice. Indian $\mathbf{J}$ Exp Biol. 2009; 47:668-71.

4. Alamgir M, Jamal Uddin Sh. A Source of Complementary Therapeutics. In: Debprasad chattopadhyay, editor. 
Recent advances on the ethnomedicinal plants as immunomodulatory agent. Research Signpost/ Kerala India; 2010. P. 227-44.

5. Elliot Middleton Jr. Flavonoids on immune and inflammatory cell function. In: Manthey, Buslig, editors. Effect of plant flavonoids on immune and inflammatory cell function. New York: Plenum Press, 1998. P. 175-182.

6. Matias DM, Leventon J, Rau AL, Borgemeister C, von Wehrden $\mathrm{H}$. A review of ecosystem service benefits from wild bees across social contexts. Ambio. 2017; 46(4):456-467.

7. Obolskiy D, Pischel I, Feistel B, Glotov N, Heinrich M. Artemisia dracunculusL. (Tarragon): A critical review of its traditional use, chemical composition, pharmacology, and safety. J Agric Food Chem. 2011; 9:17-45.

8. Aglarova AM, Zilfikarov IN, Severtseva OV. Biological characteristics and useful properties of tarragon (Artemisia dracunculus L.)- A Review. Pharm Chem J. 2008; 42(2):31-5.

9. Ribnicky DM, Poulev A, Watford M, Cefalu WT, Raskin L. Antihyperglycemic activity of tarralinum, an ethanolic extract of Artemisia dracunculus L. Phytomedicine. 2006; 13(8):550-7.

10. Lopes-Lutz D, Alviano DS, Alviano CS, Kolodziejczyk PP. Screening of chemical composition, antimicrobial and antioxidant activities of Artemisia essential oils. Phytochemistry. 2008; 69(8):1732-8.

11. Bayrami G, Boskabady MH. The potential effect of the extract of Crocus sativus and safranal on the total and differential white blood cells of ovalbumin-sensitized guinea pigs. Res Pharm Sci. 2012; 7(4):249-55.

12. Benjamini E, Sunshine G, Coico R. A Short Course Immunology. 5rd ed. New York: Willy-Liss Press; 2003. P. 32-40.

13. Noori M, Abadi A, Hojjati MR, Sedighi M. Effect of hydro-alcoholic extract of Ziziphus Jujuba on the peripheral blood cells in Balb/c mice. Physiology and Pharmacology. 2013; 17(2): 224-30.

14. Ghanadian M, Ayatollahi AM, Afsharypour S, Hareem S, Abdalla OM, Bankeu JJK. Flavonol glycosides from Euphorbia microsciadia Bioss. with their immunomodulatory activities. Iran J Pharm Res. 2012; 11(3): 925-30.

15. Amirghofran Z, Bahmani M, Azadmehr A, Javidnia K, Miri R. Immunomodulatory activities of various medicinal plant extracts: effects on human lymphocytes apoptosis. Immunol Invest. 2009; 38(2):181-92.

16. Yapo FA, Yapi FH, Ahiboh H, Hauhouot-Attounbre, ML, Guede NZ, Djaman JA, Monnet D. Immunomodulatory effect of the aqueous extract of Erigeron floribundus (Kunth) Sch Beep (Asteraceae) leaf in rabbits. Trop $\mathrm{J}$ Pharm Res. 2011; 10(2):187-93.

17. Sharifian Z, Vodgani M, Hajati pour J, Kamalinejad M. Immunological effects of Teucrium polium on neutrophils. Proceeding of the 2th International congress on traditional medicine and materia medica. 2004 Oct 4-7; Tehran, Iran.

18. Abbas Ak, Lichtman AH, Pillai S. Cellular and Molecular Immunology. Philadelphia: Saunders Press; 2012. P. 280-9. 